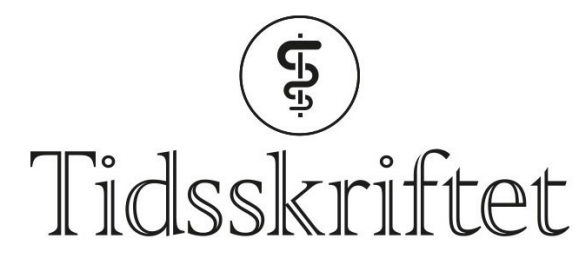

DEN NORSKE LEGEFORENING

\title{
Om mopeder og kirurger
}

MINILEDER

ARE BREAN

Sjefredaktør

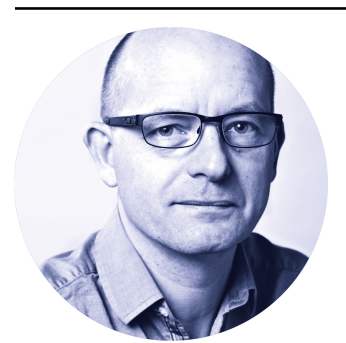

For å få førerkort for moped i Norge kreves det minimum 28 timers opplæring, hvorav en praktisk del på minimum åtte timer, i tillegg til et antall kjøretimer med lærer. Det er forståelig - en moped kan i uøvde hender være et farlig redskap.

For å bli legespesialist, derimot, skal det heretter ikke bli slike tallfestede krav. Helsemyndighetene dropper kravet om obligatoriske prosedyrelister i den nye spesialistutdanningen. I stedet nedfeller Helsedirektoratet kravene til operasjonsvolum kun som anbefalinger. Fagmiljøene er i harnisk.

Myndighetenes uvilje mot å tallfeste nødvendig operasjonsvolum truer ideen om en enhetlig nasjonal spesialistutdanning for leger. Minimumskrav sikrer en felles minstestandard. Det gjelder både for mopedister og for kirurger. I mangel på rasjonelle forklaringer bak vedtaket er det lett å ty til de konspiratoriske: Er det de regionale helseforetakene, med sine mange grunner til å ønske seg regionalisering av spesialistutdanningen, som spøker i bakgrunnen her? Når en vakthavende ortoped i Bergen ikke lenger skal tilsvare en fra Trondheim, gjelder det i fremtiden å vurdere nøye hvor man tør kjøre sin moped.

Publisert: 8. mai 2018. Tidsskr Nor Legeforen. DOI: 10.4045/tidsskr.18.08.01

(C) Tidsskrift for Den norske legeforening 2020. Lastet ned fra tidsskriftet.no 